\title{
Federal Government and Production
}

\author{
By Grant Hamilton
}

Formerly Director Working Conditions Service, United States Department of Labor; now Special Immigrant Inspector

WaT can the government do
for production? According to past political thought the best thing the government could do was to keep its hands off except when the exercise of police power was necessary to maintain property rights. However, there has been developing a larger concept of governmental functionsconstructive as well as punitive duties.

Dissatisfaction with inefficiency that has developed under private control has led some enthusiasts to suggest and urge as a solution of production problems that all or some of the large industries be nationalized. That solution would involve production in all the evils of the bureaucratic system, would deaden individual initiative and would halt production progress by the perversions of majority decisions, quantity values and the negligible consideration which politics gives to facts and scientific law.

All progress is individual and begins with basic things first. Therefore, this discussion can wisely ignore the socialistic theory of governmental functions and consider only what the government can contribute to production under private initiative.

In the constructive field, governmental work is most effective when it has the least mandatory power. When government service to be effective must win for itself confidence and leadership, it is forced to ground its activity upon facts and laws-the test of permanent production efficiency.
Need for Industrial Research

Industry needs facts. The main difficulty with production in the past is that it has not trusted its success to exact information, knowledge and application of the best methods, but to manipulation and securing profits by some trick of exploitation. That phase of business is passing; business men are beginning to understand that exploitation does not pay in the long run. Waste, whether of human or material elements, means financial losses. Receipts really represent the social service the industry is able to perform. Whatever curtails social service will eventually curtail profits. It pays in dollars and cents as well as morality to run business in accord with the concept of social service. This concept presupposes that all elements and functions concerned in production are to be administered with highest effectiveness, in accordance with the best understanding and information. It is apparent how large a place information has in production. Of the gathering of information there seems no end. But the value of the information is conditioned by the method of inquiry, the purpose, the personal equations of the investigators.

Industrial information becomes available through research. No research can maintain itself entirely independent of influences from its sources of revenue. When the purpose of the research is served by scientific impartiality - as in the case of industrial formulas-private revenues are not detrimental. However, 
when the research deals with matters that concern human interests there is but one agency that stands for the welfare of citizenship as a whole, and that agency should be preëminent in that field.

The human element in production was pretty generally ignored by technicians, managers and employers until attention was focussed by the militant tactics of trade unions. Countermilitancy, on the part of employers, resulted only in strife and waste. Finally, some of the wiser managers discovered that labor organizations facilitated administrative purposes, if the management could develop good will and coöperation of workmen, instead of hostility and distrust. This concept led to the questions:

"What administrative policies will remove the causes of militancy? What methods will develop good will, and how can we help to release the full producing power of workers?"

This field of personnel relations involves the heart of the labor problem and the future of production progress. Information as to theories, methods, and experiments is of fundamental importance to industry and to the state. There are many individuals, voluntary organizations and foundations doing valuable work in this field-work which would be of incalculable value to individual managers if made available for their use.

In order to make present knowledge available for use and for continued investigation there ought to be a national clearing house of information. We can safely entrust such a function only to an agency as fully representative of all national interests as possible, and equally free from non-social interests. A governmental agency has the advantage of freedom from private contributions, which more or less dictates personnel or conclusions.
Endow such an agency with advisory and informational powers only and it will be forced by the law of selfpreservation to avoid the more entangling and malevolent tendencies of the ordinary governmental bureau. A governmental service is forced by its nature to adopt policies of business efficiency. In addition, there is an authority sustaining a governmental research or recommendation that cannot be attained by voluntary organizations or unofficial presentation.

While it is maintained that a government agency should be established for leadership in the field of personnel relations, this conclusion does not even suggest the abolition of voluntary organizations or individual research. On the contrary, the governmental agency should serve as the coördinating body to facilitate and unify various efforts and to promulgate findings. Such advisory and coöperative relations could be established with private research agencies, that by mutual agreement and conformity to standards of methods and tests, private research and professional work could acquire the authority of governmental endorsement.

\section{GOVERNMENT FUNCTIONS IN Production}

Having thus considered the advisability of the government's participation in the constructive field of production, the next step necessary is to briefly consider what functions it should perform:

First-It should establish a national clearing house for information upon personnel relations.

Second-It should place this information in thehands of responsible heads of industry in a form usable in their practical problems.

Third-It should maintain a staff of experts and specialists available to 
any industry for consultation purposes. (This function would not interfere with those who are entering the developing profession of personnel administration, but, on the contrary, would open new opportunities for their service.)

\section{Effect of Government Partici- pation in Production}

The result of this governmental service would help to remove causes of industrial strife, develop the opportunity and the method for coöperation between management and workers for improved production, and establish in industrial government those principles which provide for the fullest development and opportunity for selfexpression of all concerned.

While it is outside the purpose of this article to deal with specific theories, yet it is felt that the service will be an ultimate failure that does not regard the spiritual element in man as the dominant force in all relations of life.

In addition to the advisory and informational service which the government ought to render industry, it should render service in two other fundamentally important capacitiesin mobilizing the working force of the country so that workers can have information of work opportunities and can find work for which they are fitted, and in helping to adjust industrial disputes.

The function named first implies constructive service of a similar nature to that concerned with personnel administration. The employment problem involves nation-wide elements and can be comprehensively dealt with only by a national agency. Maintenance of an adequate, as well as an efficient and stable working group is necessary to most effective production.

In the third place the government should assist in adjusting industrial breakdowns in order to further the best interests of those concerned in the industry, as well as the consuming public. Here again the government can be most helpful in an advisory capacity. Leadership, rather than mandatory power, brings the best longtime results. This in such industrial emergencies leads naturally to the larger constructive service which the government can render in helping industries to avoid industrial catastrophies by removing the causes of friction, and providing adequate opportunities for constructive use of energy. 